\title{
Valuing Carbon Sequestration to Finance Afforestation Projects in China
}

\author{
Guolong Hou ${ }^{1,2} \mathbb{D}$, Claudio O. Delang ${ }^{1}$, Xixi Lu ${ }^{3,4}$ and Roland Olschewski ${ }^{2, *}$ \\ 1 Department of Geography, Hong Kong Baptist University, Kowloon Tong 999077, Hong Kong SAR, China \\ 2 WSL Swiss Federal Research Institute, Environmental and Resource Economics, Zürcherstr. 111, \\ Birmensdorf CH-8903, Switzerland \\ 3 Department of Geography, National University of Singapore, 1 Arts Link, Kent Ridge, \\ Singapore 117570, Singapore \\ 4 Inner Mongolia Key Lab of River and Lake Ecology, Inner Mongolia University, Hohhot 010021, China \\ * Correspondence: roland.olschewski@wsl.ch; Tel.: +41-447-392-562; Fax: +41-447-392-215
}

Received: 14 July 2019; Accepted: 27 August 2019; Published: 2 September 2019

check for updates

\begin{abstract}
Afforestation programs have huge potential to store carbon, thereby contributing to mitigate climate change. However, the voluntary acceptance by landowners crucially depends on their economic outcome. We (i) assess the carbon sequestration potential of afforestation projects in various Chinese regions by comparing different tree species, project durations and regional particularities, (ii) analyze the costs and benefits of tree species used for timber and fruit production as well as bamboo, and (iii) compare them with alternative crops under different climatic and economic conditions. Finally, we calculate the minimum compensation required by farmers to convert cropland to forests assuming a joint production of timber or fruits and carbon sequestration. No compensation is needed when cropland with relatively low revenues is to be converted. In contrast, compensation payments must be high for converting land used for cash crops, such as sugarcane. For fruit trees, the amount of carbon sequestered is low, but selling fruits and nuts is quite profitable. Consequently, in most cases there is no compensation needed. The minimum price per carbon credit decreases with increasing project duration because more carbon is stored per hectare, and in consequence, the required payments per credit are lower. This does not hold for fast-growing trees like eucalyptus and poplar, for which the minimum price increases with extended project duration. Bamboo shows a high carbon sequestration potential, and becomes economically more attractive by including carbon revenues. Carbon credits can often compensate the opportunity costs of alternative land uses, except for afforestation on highly productive cropland. We demonstrate that the economic attractiveness of afforestation projects is strongly context dependent and varies substantially across regions. The findings can contribute to the cost-efficient design of carbon sequestration projects. The methodology can be applied to other regions in the developing world.
\end{abstract}

Keywords: Certified Emission Reductions; net present value; carbon price; Grain for Green program

\section{Introduction}

Forests have great potential to store carbon, which contributes to reduce atmospheric carbon dioxide concentrations [1]. Globally, forestland has the capacity to sequester $2.4 \pm 0.410^{9} \mathrm{Mg}$ of carbon emissions annually, equivalent to $25 \%$ of the global carbon emissions from fossil fuels used in 2018 [2,3]. A recent study has found an even higher potential and identified China as one of the most appropriate countries for afforestation efforts [4].

Economic incentives play an important role in the success of afforestation projects [5,6], especially in the beginning because it takes a number of years for newly planted forests to generate revenues 
through marketable products [7]. Le et al. (2014) advocate national governments to make strong efforts over a long time to provide incentives in the form of payments for plantings [5], and several countries have already realized national investments in afforestation projects. For example, the Chinese government has invested about Yuan 431.8 billion (USD 64.8 billion) in the Grain for Green program (GfG) from 1999 to 2015 to afforest marginal cropland [8]. However, such kind of massive afforestation is hardly feasible for most countries and rather the exception than the rule. In general, afforestation projects can be financed at the national level, such as China's GfG program, or at the international level, e.g. by issuing and trading Certified Emission Reductions (CER). Internationally, the most important market for carbon credits was created under the Kyoto Protocol starting in 2000 via the Clean Development Mechanism (CDM) or during 2008-2012 via Joint Implementation (JI) [9].

Whether financial incentives are sufficient to convince landowners to participate in afforestation projects depends primarily on the comparison of costs and benefits of such projects [10]. There have been cost-benefit analyses of carbon sequestration by afforestation in several countries, such as Canada [11], Argentina and Ecuador [12], as well as Australia [13]. However, to our knowledge, there are only few studies analyzing the economic attractiveness of afforestation projects in China that take full account of the carbon sequestration value. One study conducted by Xu in 1995 calculated the amount of carbon sequestered through large-scale afforestation and the related costs and benefits [14]. However, timber prices and labor costs have changed substantially in recent years, and they can vary greatly among different regions [14]. Caldwell et al. (2007) and Wang et al. (2007) assessed the cost-effectiveness of projects at the municipality level, which makes their results hardly transferable to other regions [15,16]. Shi and Wang (2011) included the benefits of carbon sequestration in the soil of farmland converted to forestland in the assessment of ecological, economic, and social impacts of the GfG program [17]. However, they only considered the carbon stocks in the topsoil (0 to $20 \mathrm{~cm}$ depth), without taking the vegetation biomass and deeper soil organic carbon (SOC) stocks into account. Furthermore, the costs and benefits of afforestation projects change with stand age because trees absorb more additional carbon dioxide when they are young, and produce more marketable products when they are older. However, only few studies in China have comprehensively analyzed the economic impact of afforestation projects comparing different tree species, project durations and regional particularities.

The economic attractiveness of forest land uses varies with the type of tree species and the level of income from alternative agricultural crops. Large variation exists in the estimated opportunity costs of agricultural production, ranging from $\$ 4.33 / \mathrm{t} \mathrm{CO}_{2}$ in Latin America to $\$ 19.49 / \mathrm{tCO}_{2}$ in Africa [18]. A review of 32 primary studies of opportunity costs, using different types of data, methods, and scales of analysis, found a wide range of costs, from $\$ 0.15$ to $\$ 339 / t \mathrm{CO}_{2}$ [19]. The authors were not able to disentangle differences that are due to the variation in actual opportunity costs related to site characteristics or local activities from those that are a 'by-product' of methodological and data choices [20]. To understand the potential impact on farmers' decision making, it is important to conduct the analyses at the household level as opposed to the national or regional level.

China is a big country with diverse climatic conditions and geographical features including soil quality, and water availability. It has undertaken large reforestation programs in most provinces, in particular since 1999. According to Delang and Yuan (2016) and Zhang et al. (2018), afforestation in China is generally based on three tree types: Ecological trees, economic trees, and bamboo [21,22]. This distinction is based on the fact that (i) the tree products are different (ecological trees and bamboo mainly produce timber, whereas economic trees mainly produce non-timber products, such as fruits, and (ii) significant differences exist concerning growth patterns and forest management. Furthermore, different tree species and crop types are grown in different regions. For example, trees like apple, poplar (Populus) and crops like wheat normally grow in the north, whereas eucalyptus, Chinese fir (Cunninghamia lanceolate (Lamb.) Hook.), mango, rice, and sugarcane usually grow in the south. Besides, harvesting practices vary in different regions. For instance, corn is normally harvested once a year in the north, but two or three times in the south. In addition, afforestation with different tree species 
may result in a significant variation of revenues from tree products. Finally, it is necessary to take the specific conditions in different regions into account. Accordingly, we address three research questions: (i) To what extent can carbon be sequestered both in tree biomass and soils through afforestation? (ii) Is it economically attractive to convert cropland into forest considering different tree species and crop types? (iii) What is the minimum price per ton of $\mathrm{CO}_{2}$ to compensate the opportunity costs of farmers when switching from alternative land uses to forestry?

To answer these research questions, we first examine the carbon sequestration potential in biomass and soil of different plant species by afforestation in several Chinese regions. Then we compare costs and benefits of alternative land uses and calculate the minimum compensation required. Finally, we compare the economic attractiveness of afforestation projects under different conditions. Considering uncertainties about future economic conditions and developments, we conduct a sensitivity analysis to evaluate the changes of minimum prices per ton of $\mathrm{CO}_{2}$.

\section{Materials and Methods}

\subsection{Study Area}

According to Fang's classification [23], China is divided into six geographical regions: Northeast China, North China, East China, Central South China, Southwest China, and Northwest China (Figure 1). The south and east of China mainly belong to the Tropics and Subtropics, while the north is a region with temperate climate. In order to cover different plant types and make the results applicable to different regions, we chose the most common species planted across five different regions except for Northeast China. The most common species used for afforestation in Northeast China is Larix, which is a deciduous softwood species. However, due to insufficient information on the soil organic carbon (SOC) stock changes after afforestation with deciduous softwood, we excluded Northeast China from this study. The analysis provides important information to classify carbon sequestration by trees based on different climatic and economic contexts.

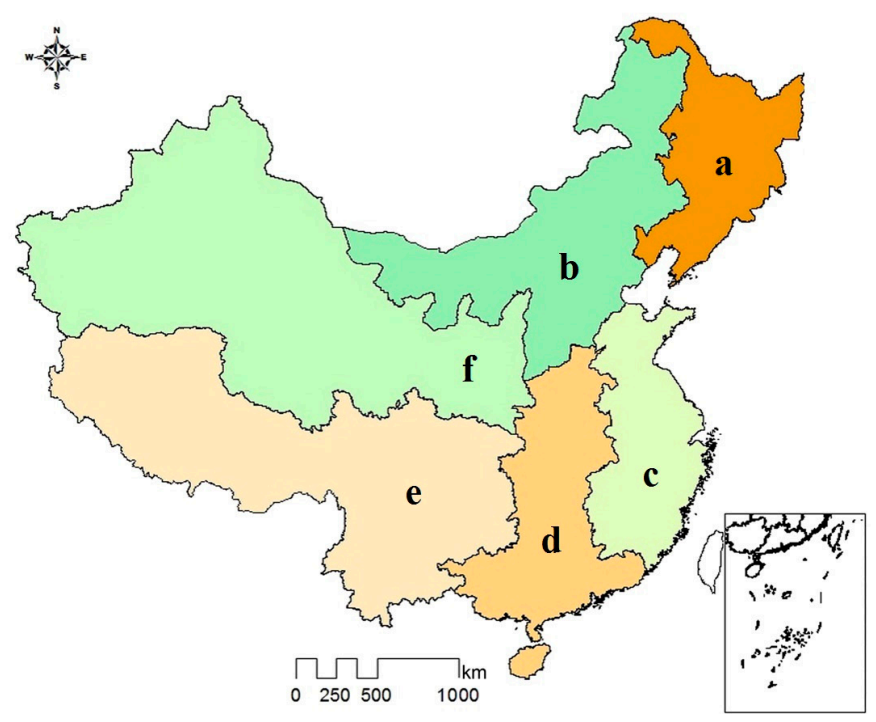

Figure 1. Six geographical regions of China. Note: (a) Northeast China; (b) North China; (c) East China; (d) South China; (e) Southwest China; and (f) Northwest China. Source: [24].

The final dataset includes three ecological trees (eucalyptus, Chinese fir and poplar) and five economic trees (apple trees in the north, orange and mango trees in the south and walnut and chestnut trees). Note that different species also represent different tree types. Poplar belongs to deciduous hardwood, eucalyptus is an evergreen hardwood, Chinese fir is an evergreen softwood, and economic trees are all deciduous hardwood. This classification not only allows us to further explore the effects of 
different values of tree products (timber or fruit) on the net income of afforestation projects but also to take the significant differences of carbon sequestration among various tree types into consideration.

To compare the income obtained from afforested land with income from cropland, we selected villages with converted land or cropland (most villages have both). The selected cropland should have similar characteristics as the converted land with respect to soil quality, water availability, slope, and other biotic and abiotic factors.

\subsection{Estimation of Carbon Sequestration}

We estimated carbon sequestration in tree biomass (above- and below-ground) and changes in SOC stocks of afforestation projects on former cropland, focusing on ecological trees, economic trees and bamboo. The forest floor was not considered in this study, because due to management practices, there was little forest litter on the ground.

\subsubsection{Carbon Sequestration by Ecological Trees}

In the present study, we assessed the carbon sequestration capacity of three different ecological trees. We used the stand growth models developed in the literature to estimate carbon sequestration in forest biomass (Table 1). The models were developed for specific species and at regional scales, which allowed us to make respective comparisons.

Table 1. Stand growth models to estimate the change of forest biomass carbon with stand age.

\begin{tabular}{llllll}
\hline \multicolumn{1}{c}{ Species } & Region (s) & Stand Growth Model & $\mathbf{R}^{\mathbf{2}}$ & $\mathbf{N}$ & RMSE \\
\hline Eucalyptus & $\mathrm{C}$ & $\mathrm{B}=272.312 \exp (-\exp (1.1458-0.1257 \mathrm{~A}))$ & 0.65 & 83 & 17.97 \\
Chinese fir & $\mathrm{E}, \mathrm{N}, \mathrm{NE}$ & $\mathrm{B}=249.6367 /(1+\exp (2.447-0.127 \mathrm{~A}))$ & 0.80 & 202 & 30.32 \\
& $\mathrm{NW}, \mathrm{S}, \mathrm{SW}$ & $\mathrm{B}=256.6336(1-\exp (-0.0322 \mathrm{~A}))^{\wedge} 1.035$ & 0.75 & 105 & 21.62 \\
Poplar & $\mathrm{E}, \mathrm{S}, \mathrm{SW}$ & $\mathrm{B}=131.5002 /(1+\exp (3.0444-0.4285 \mathrm{~A}))$ & 0.74 & 98 & 22.27 \\
& $\mathrm{~N}, \mathrm{NE}, \mathrm{NW}$ & $\mathrm{B}=86.0127 /(1+\exp (3.621-0.2344 \mathrm{~A}))$ & 0.89 & 57 & 10.31 \\
\hline
\end{tabular}

Source: [22]. Note: A and B represent stand age (year) and forest biomass carbon $\left(\mathrm{Mg} \mathrm{ha}^{-1}\right)$, respectively. $\mathrm{C}, \mathrm{E}, \mathrm{N}$, $\mathrm{NE}, \mathrm{NW}, \mathrm{S}$, and SW are abbreviations for China, and the eastern, northern, northeastern, northwestern, southern, and southwestern region. RMSE is the root mean square error $\left(\mathrm{Mg} \mathrm{ha}^{-1}\right)$.

For carbon sequestration in soils, we considered the top $60 \mathrm{~cm}$ soil layer, which contains around $70 \%-80 \%$ of the first-meter SOC stocks, and is mostly affected by land-use change $[25,26]$. Several studies have shown the significant effects of tree types and stand ages on SOC sequestration capacities (e.g. $[27,28]$ ). However, these studies usually divide trees into hardwood and softwood, broadleaf and conifers or evergreen and deciduous $[27,28]$, which may result in some overlap. For instance, species in genera such as eucalyptus could be viewed as hardwood and evergreen. In our study, we suggest a classification as (i) deciduous hardwood, (ii) evergreen hardwood and (iii) evergreen softwood. We used the results of our own meta-analysis based on world-wide data [29]. Table 2 shows how SOC sequestration changes after afforestation with deciduous hardwood, evergreen hardwood or evergreen softwood on cropland at different stand ages.

Table 2. Soil organic carbon (SOC) storage change $\left(\mathrm{Mg} \mathrm{ha}^{-1} \mathrm{yr}^{-1}\right)$ of different age groups after afforestation with various tree types (0-60 cm layer).

\begin{tabular}{cccc}
\hline \multicolumn{3}{c}{ Plant Types } \\
\hline A (yr) & Deciduous Hardwood & Evergreen Hardwood & Evergreen Softwood \\
\hline$\leq 10$ & $0.20( \pm 1.71)$ & $-0.24( \pm 0.71)$ & $-1.07( \pm 1.74)$ \\
$11-20$ & $0.90( \pm 1.06)$ & $-0.29( \pm 1.91)$ & $-0.77( \pm 1.08)$ \\
$21-30$ & $0.65( \pm 0.48)$ & $2.55( \pm 1.29)$ & $0.57( \pm 0.99)$ \\
$31+$ & $0.72( \pm 0.24)$ & $1.40( \pm 0.81)$ & $0.39( \pm 0.24)$ \\
\hline \multicolumn{4}{c}{ Note: A $=$ stand age in years. }
\end{tabular}

Note: $\mathrm{A}=$ stand age in years. 
SOC is continuously sequestered after afforestation with deciduous hardwood. Higher sequestration rates are observed after the first decade (Table 2). For evergreen plants, hard- as well as softwood experience a loss of SOC stock in the first two decades, while afterwards evergreen hardwood sequesters more SOC than the other two tree types. In general, they achieve the greatest SOC sequestration before the fourth decade, with some variation for deciduous hardwood.

\subsubsection{Carbon Sequestration by Economic Trees}

Wu et al. (2012) estimated the carbon sequestration capacity of apple trees at various ages in China's major apple regions and found the net carbon uptake is -7 (source until year 5), +19 (until year 18), and $+17 \mathrm{Mg} \mathrm{ha}^{-1}$ (until year 22) [30]. They conclude that apple orchards older than 8 years can be considered as a carbon sink. At the age of about 18, they reach the peak of carbon sequestration capability, which then begins to decline. The relationship between tree age $\left(\mathrm{X}_{\mathrm{age}}\right)$ and $\mathrm{C}$ sequestration $\left(\mathrm{C}_{\mathrm{seq}}\right)$ can be expressed as Equation (1):

$$
C_{\text {seq }}=-0.1471 X_{\text {age }}^{2}+5.3824 X_{\text {age }}-30.235
$$

For South China, Ren et al. (2014) estimated that the carbon accumulation in the biomass of orchards in Hainan was $21.8 \mathrm{Mg} \mathrm{ha}^{-1}$ at a stand age of 15, which is applied in the present study for tropical fruit trees such as mango [31]. For carbon sequestration of walnut trees in North China, we applied the findings from Shen et al. (2017), who calculated a biomass carbon sequestration of 10-year old walnut trees of $8.749 \mathrm{Mg} \mathrm{ha}^{-1}$ [32]. For chestnut trees, Peng and Wang (1998) determined the respective dry biomass for different trees densities [33]. In our study, we apply the results of lowest density since this is consistent with the density farmers usually plant: 11.6 (for tree age 1-4), 18.12 (for age 5-6), and $28.88 \mathrm{Mg} \mathrm{ha}^{-1}$ (for more than 7 years).

For SOC sequestration of these three tree types, we used the data of deciduous hardwood (compare Table 2), because economic trees normally belong to this type of wood.

\subsubsection{Carbon Sequestration by Bamboo}

Bamboo forest is one of the most important forest types in the world, and is mainly distributed in the tropical and subtropical regions [34]. In China, bamboo forests are mainly found in the south adding up to 6 million ha and accounting for 3\% of the total forest area [35]. Moso bamboo (Phyllostachys pubescens Mazel ex Houz.) forests cover 4.43 million ha (74\% of all bamboo forests). According to Zhang et al. (2014), the estimated annual carbon sequestration in the biomass of moso bamboo forests in southern China is $6.74 \mathrm{Mg} \mathrm{ha}^{-1}$ [34]. In our study, we apply this annual quantity of carbon accumulation because (i) the estimation was based on regional scale data from South China, which is the area under consideration in our study; (ii) the estimated overall carbon storage in the study area was $40.45 \mathrm{Mg} \mathrm{ha}^{-1}$, which is consistent with previous studies [36]; and (iii) it reflects the regional management practices, where annually $1 / 6$ of older culms from the moso bamboo forest are harvested by selective cutting.

For SOC sequestration of bamboo, we applied the results of evergreen hardwood species (compare Table 2), because bamboo (i) retains green leaves throughout the year; (ii) has flat leaves rather than needle-like leaves; and (iii) grows in high density.

\subsubsection{Temporal Patterns of Carbon Sequestration}

To obtain information on the changes of carbon sequestration with stand ages, we performed regression analyses to develop the functions expressing the temporal patterns of carbon sequestration for each species. All statistical analyses were performed using SPSS, ver. 25.0 (SPSS Inc., Chicago, IL, USA). 


\subsection{Economic Analysis}

Our economic analysis focuses on the net income of afforestation activities and the opportunity costs of alternative land uses. We assess afforestation alternatives with different tree species, project durations and crop types. Then, we determine the costs of carbon sequestration for different scenarios.

\subsubsection{Collection of Economic Data}

Economic data were gathered through interviews with farmers in different regions, where we collected soil and biomass data in parallel. The interviews were conducted from July to August 2018 and April to May 2019. First, we selected a region in terms of (i) abundance of the tree or crop species we had selected, and (ii) physical accessibility. In the region, we used two approaches. The first was to randomly select villages, and within the villages randomly select interviewees to carry out door-to-door interviews. However, this procedure was not successful because of difficulties to find farmers who had planted our selected tree or crop species. The alternative approach was to ask the village committee to provide us with the phone numbers of farmers who had planted our selected trees or crop species, and we randomly select households from the list for face-to-face or phone interviews. We met and called more than 200 people, and 75 provided information that we considered reliable (five for each species).

We first asked farmers for the tree species they planted, the planting density and the stand age. The stands had to fulfill the following requirements: (i) planted as monocultures, (ii) managed to assure a survival rate of at least $70 \%$, and (iii) no large-scale cutting. If these criteria were satisfied, we asked farmers, which costs and benefits they had when planting trees. The costs include (i) site preparation (preparation of the land and planting, seedlings or sapling); (ii) management (insecticides, herbicides, fertilizer, manual cleaning and weeding, pruning and thinning; replanting); (iii) harvest and (iv) tools and machinery. The benefits comprise (i) income from timber/wood use and/or (ii) sale of non-timber forest products (e.g. fruits, mushrooms, medicinal plants). To obtain an overview of the overall lifecycles, we collected data from farms with different stand ages. The information of economic costs and benefits of farmland were also collected through interviews with farmers who have participated in the afforestation program but still have cropland to cultivate as well as non-participants. These costs comprise site preparation, management, harvest and tools, while benefits stem from selling the harvested crops.

Local market prices are used to value traded forest and agricultural products. In case marketable products are not sold but consumed by the farmers, the market price is used for valuation, too, since directly consumed products increase the standard of living of farmers similar to the income generated by selling products. For each item, labor costs were considered. Since the labor price varied substantially among different regions, we used the local labor costs in each region.

\subsubsection{Net Income Comparison of Forest and Cropland}

A comparison of costs and benefits of the different land-use types was made to assess the attractiveness of afforestation investments. We applied the net present value (NPV) criterion shown in Equations (2) and (3).

$$
\mathrm{NPV}=\mathrm{PV}(\text { Benefits })-\mathrm{PV}(\text { Costs })
$$

Benefits $(B)$ and costs $(C)$ occur at different times $(t)$ and are to be discounted $(\mathrm{d}=$ discount rate) in order to make them comparable:

$$
\mathrm{NPV}=\sum_{t=0}^{T} \frac{B_{t}}{(1+d)^{t}}-\sum_{t=0}^{T} \frac{C_{t}}{(1+d)^{t}}
$$


We assume that a profit-maximizing and risk-neutral landowner would switch from crop farming to afforestation if the NPV of the afforestation $\left(\mathrm{NPV}_{\mathrm{A}}\right)$ is higher than or at least as high as the NPV of crops $\left(\mathrm{NPV}_{\mathrm{C}}\right)$.

$$
\mathrm{NPV}_{\mathrm{A}} \geq \mathrm{NPV}_{\mathrm{C}}
$$

If the $\mathrm{NPV}_{\mathrm{A}}$ is lower than $\mathrm{NPV}_{\mathrm{C}}$, we can assess whether the revenues of carbon sequestration (as a reward for the service provided by the landowner) could compensate for the net loss of switching to forestry [37].

$$
\begin{aligned}
& \mathrm{NPV}_{\mathrm{A}}+\mathrm{PV}_{\mathrm{CR}} \geq \mathrm{NPV}_{\mathrm{C}} \\
& \mathrm{PV}_{\mathrm{CR}} \geq \mathrm{NPV}_{\mathrm{C}}-\mathrm{NPV}_{\mathrm{A}}
\end{aligned}
$$

$\mathrm{PV}_{\mathrm{CR}}$ is the present value of carbon revenues required to make forest an economically attractive alternative. These revenues occur, e.g., if Certified Emission Reduction units (CERs) are issued and sold on a market. As a result, the landowner might have an economic incentive to convert cropland to forest with the aim to jointly produce timber and carbon credits.

For discounting, we applied an interest rate of $4 \%$, which is the average interest rate of 3-years Chinese national bonds in recent years (see https://www.chinabond.com.cn/). Because of uncertainties about future developments, we conducted a sensitivity analysis applying different interest rates, prices and rotation lengths.

\subsubsection{Afforestation Scenarios}

According to the UNFCCC (2013) rules, a CDM afforestation project can choose to prepare its first monitoring report (for the 'initial verification and certification') at any time [38]. It could be 10 years for a slow-growing forest, or e.g., five years for a fast-growing plantation. However, after the initial verification and certification of carbon stocks within the project boundary, verification and certification must be carried out every five years until the end of the crediting period. Therefore, forest projects starting in 2019 would have their carbon sequestration verified in 2024 or 2029, and the temporary CER (tCER) would expire in 2029 and 2034, respectively. Given these assumptions, tCER would always be valid for at least five years. Projects can have (i) a single fixed crediting period of up to thirty years; (ii) a renewable crediting period of up to twenty years, which can be renewed at most twice. Therefore, the maximum length of the crediting period of a project can be sixty years, if successfully renewed twice [38]. The costs of certification include project design and validation, carbon accounting and monitoring. Since no information was available about the exact certification costs in China, we neglected these costs in the main analysis and additionally conducted a sensitivity analysis to assess how certification costs can influence the minimum prices per tCER (see Section 3.3)

Wang et al. (2007) analyzed two afforestation scenarios with different lengths of the evaluation period [16]. The first coincided with the national subsidy period for ecological trees in China (8 years); the second with the rotation period of 40 years for Larch, the tree species they studied. However, national subsidies will no longer play an important role in the determination of the evaluation period because (i) they are fading out from 2015 on (with a respective delay in areas where it started later) [21] and (ii) in the new period of the afforestation program, farmers can choose to plant ecological or economic trees with the same level of subsidies. In our study, a 30-year evaluation period was chosen because tree growth rates and SOC sequestration rates would decline afterwards (Tables 1 and 2). Thus, we assumed a project duration of 30 years with carbon credits verified and issued every five years. The $\mathrm{PV}_{\mathrm{CR}}$ of a 30-year project is determined by equation (7) [12,39]:

$$
\mathrm{PV}_{\mathrm{CR}}=\frac{\mathrm{ptCER}_{5} \times \mathrm{C}_{5}}{(1+\mathrm{d})^{5}}+\frac{\mathrm{ptCER}_{10} \times \mathrm{C}_{10}}{(1+\mathrm{d})^{10}}+\cdots+\frac{\mathrm{ptCER}_{25} \times \mathrm{C}_{25}}{(1+\mathrm{d})^{25}}
$$

ptCER $\mathrm{t}_{\mathrm{t}}$ the price for one tCER at time $t, \mathrm{C}_{t}$ is the net amount of $\mathrm{CO}_{2}$ stored at time $t$, and $d$ is the discount rate. Carbon remaining in products made from harvested timber is not considered. 
The minimum price per ton of $\mathrm{CO}_{2}$ (ptCER) to make farmers switch from crop production to forestry can be calculated by the following equation [12]:

$$
\text { ptCER }=\frac{\mathrm{NPV}_{\mathrm{C}}-\mathrm{NPV}_{\mathrm{A}}}{\frac{\mathrm{C}_{5}}{(1+\mathrm{d})^{5}}+\frac{\mathrm{C}_{10}}{(1+\mathrm{d})^{10}}+\cdots+\frac{\mathrm{C}_{25}}{(1+\mathrm{d})^{25}}}
$$

In this study, we only conducted the economic evaluation for one rotation with different project durations because carbon sequestration data for successive rotations were not available. On the one hand, we determined the economic benefits of the same species across different regions since the carbon sequestration potential varies significantly among them. On the other hand, we compared conversion of cropland to various forest alternatives within the same region because the species commonly planted differ among regions. Furthermore, we compared the $\mathrm{PV}_{\mathrm{CR}}$ of a 30-year rotation with various rotation periods typically applied by farmers. For example, farmers who plant eucalyptus usually harvest it after five years, but this is too short to generate carbon credits. Therefore, we analyzed whether it would be more beneficial if timber is harvested after 10, 20, and 30 years, respectively. Figure 2 exemplifies possible carbon revenues generated by an afforestation project with different project durations.

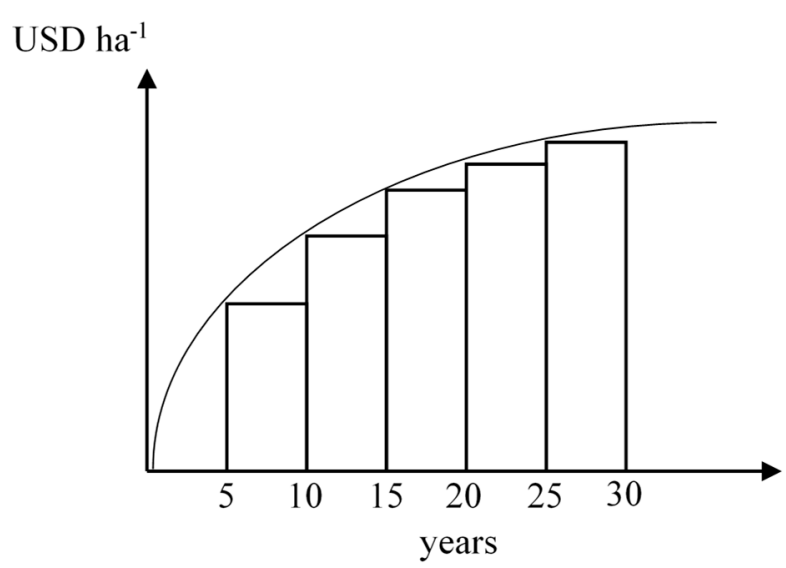

Figure 2. Revenues of carbon sequestration $\left(\mathrm{USD} \mathrm{ha}^{-1}\right)$ by an afforestation project with different project durations.

To assess the timber production for a longer project duration, we applied the allometric growth models of stand volumes from literature (Table 3). Note that the price per $\mathrm{m}^{3}$ of timber could increase with diameter and stand age. Therefore, we asked farmers about the price of timber stemming from bigger trees. However, farmers had hardly any information since they rarely harvest and sell such timber. Thus, we had to refer to recent market prices reported at http://www.chinatimber.org/.

Table 3. Timber production $\left(\mathrm{m}^{3} \mathrm{ha}^{-1}\right)$ by different tree species estimated by allometric growth models.

\begin{tabular}{cccc}
\hline Species & Growth Curve & $\mathbf{R}^{\mathbf{2}}$ & Reference \\
\hline Eucalyptus & $\mathrm{V}=208.29\left(1-\mathrm{e}^{\wedge}(-0.3320 \mathrm{~A})\right)^{\wedge} 2.0767$ & 0.994 & {$[40]$} \\
Chinese fir & $\mathrm{V}=308.64\left(1-\mathrm{e}^{\wedge}(-0.1216 \mathrm{~A})\right)^{\wedge} 4.2178$ & 0.925 & {$[41]$} \\
Poplar & $\mathrm{V}=365.50\left(1-\mathrm{e}^{\wedge}(-0.1848 \mathrm{~A})\right)^{\wedge} 3.9547$ & 0.998 & {$[42]$} \\
\hline \multicolumn{2}{l}{ Note: $\mathrm{V}$ and A represent timber production $\left(\mathrm{m}^{3} \mathrm{ha}^{-1}\right)$ and stand age (year), respectively. }
\end{tabular}

\section{Results and Discussion}

\subsection{Carbon Sequestration by Afforestation}

The carbon sequestration potential differs among tree species and stand age as well as across regions (Table 4). In warmer and more humid climates, as in the southern and eastern regions, trees 
sequester carbon faster than in other regions due to the higher initial growth rate in a tropical climate. The temporal patterns of carbon sequestration including both tree biomass and soils by afforestation are shown in Figure S1 in Supplementary. Carbon sequestration rates of ecological trees achieve their peaks 25-30 years after planting, except poplar in E, S, and SW of China, where it accumulates most carbon before the age of 20. In contrast, fruit trees sequester less carbon because of the annual harvest of fruit products [30]. Fruit trees in the northern region are a net carbon source in the initial 8 years and after 30 years. For southern fruit trees and walnut trees, the rates of carbon sequestration peak at the age of 20, i.e., five years earlier than ecological trees. Bamboo shows a higher carbon sequestration potential than other species except eucalyptus (Table 4). It sequesters even more additional carbon in older stands (Figure S1).

Table 4. Total carbon sequestration $\left(\mathrm{Mg} \mathrm{ha}^{-1}\right)$ after afforestation with various species on cropland in different regions.

\begin{tabular}{llrrrrrr}
\hline & & \multicolumn{7}{c}{ Stand Age (Year) } \\
\hline Species & Region (s) & $\mathbf{5}$ & $\mathbf{1 0}$ & $\mathbf{1 5}$ & $\mathbf{2 0}$ & $\mathbf{2 5}$ & $\mathbf{3 0}$ \\
\hline Eucalyptus & C & 49.1 & 103 & 168 & 234 & 294 & 336 \\
Chinese fir & E, N, NE & 26.8 & 47 & 83.4 & 129 & 178 & 222 \\
& NW, S, SW & 28.5 & 55.7 & 85.8 & 117 & 149 & 178 \\
Poplar & E, S, SW & 51.1 & 103 & 135 & 150 & 152 & 145 \\
& N, NE, NW & 7.28 & 26.1 & 52.6 & 78.8 & 97 & 99.3 \\
Fruit & N, NE, NW & -7 & 8.88 & 17.4 & 18.6 & 12.4 & -1.2 \\
& S & 8.8 & 20.9 & 33.3 & 44.8 & 54.2 & 60.6 \\
Chestnut & E & 18.9 & 28.8 & 35.2 & 38.8 & 40.4 & 40.7 \\
Balnut & N & 5.92 & 15.2 & 24.7 & 33.3 & 39.9 & 43.3 \\
Bamboo & S & 28.3 & 58.8 & 103 & 158 & 222 & 291 \\
\hline
\end{tabular}

Note: C, E, N, NE, NW, S, and SW are abbreviations for China, and the eastern, northern, northeastern, northwestern, southern, and southwestern region. Apple trees are the main fruit trees studied in the N, NE, and NW regions. Fruit trees in the southern region are mango and orange.

\subsection{Economic Evaluation of Converting Cropland to Forest}

We compare the economic results of afforestation alternatives and cropland. Table 5 shows the NPV changes of various tree species and crop types with different project durations. In many cases, afforestation generates a higher net income than cropland. However, in most situations two-harvest corn or one-harvest sugarcane generate a higher NPV than afforestation alternatives (Table 5). Two-harvest corn grown in the tropical area generates an NPV (ranging from 6731 to 26,146 USD ha ${ }^{-1}$ for five years and 30 years, respectively) more than two times higher than that of one-harvest corn (ranging from 1093 to 3661 USD ha $^{-1}$ for five years and 30 years, respectively), due to higher yields and selling prices. In China, sugarcane is a cash crop with high economic returns. This leads to high opportunity costs of converting cash crops to forests. The $\mathrm{NPV}_{\mathrm{A}}$ of ecological trees and bamboo are mainly based on the income from timber products, depending on the growth rate of timber volume. In the first decades, eucalyptus, as a fast-growing tree species, generates a NPV $\mathrm{A}\left(7365 \mathrm{USD} \mathrm{ha}^{-1}\right.$ ) higher than crops, such as one annual harvest of wheat (2956 USD ha ${ }^{-1}$ ) or corn (1991 USD ha ${ }^{-1}$ ), or two harvests of rice (2606 USD ha ${ }^{-1}$ ). After 20 years, growth rates decline, which results in a decreasing present value of net revenues from timber. In contrast, bamboo grows fast during the whole study period because it is self-regenerating. Therefore, afforestation with bamboo produces a higher NPV than that of one-harvest corn after the first decade (Table 5). However, the lower price of bamboo makes it economically less attractive compared to other afforestation alternatives. For economic trees, the NPV is often higher than that of crops because selling fruits is much more profitable than selling grains. The result holds even when taking into account the relatively low revenues of fruit trees during the first 5-10 years. This is due to the fact that fruit trees normally need 7-8 years to achieve their full fruit-producing potential. In our study, we assume a constant fruit yield once the trees have achieved 
this potential. This might lead to a possible overestimation of the revenues, if fruit trees tend to produce less fruits after a few decades [30].

Table 5. Economic assessment of afforestation with various tree species and different rotation periods.

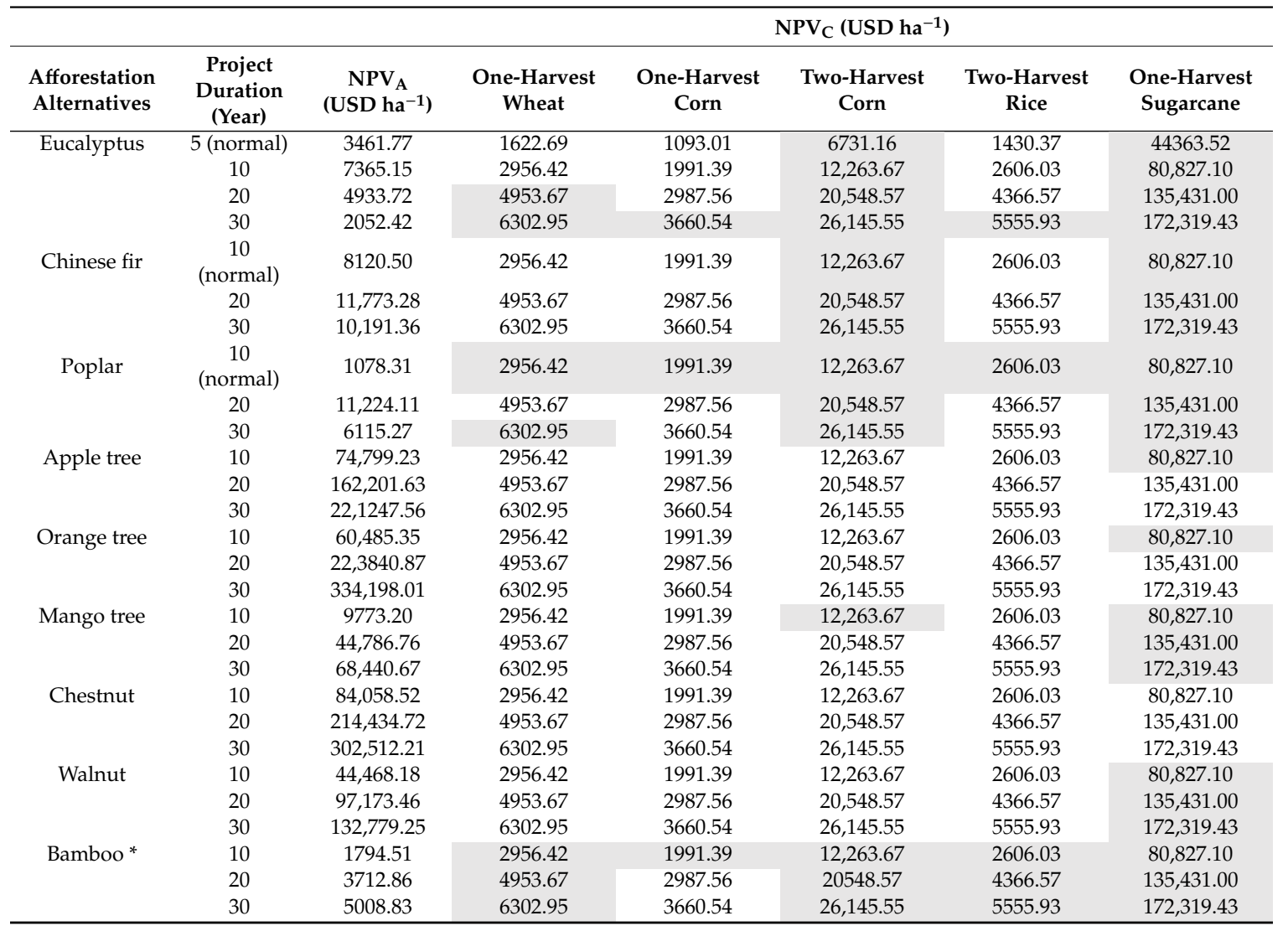

Notes: normal means the common rotation period applied by farmers. One- or two-harvest means the crops are harvested once or twice annually, respectively. ${ }^{*}$ We assume $1 / 6$ selective harvest after the first 3 years, clear-cut at the end of each rotation period. $1 \mathrm{RMB}=0.15 \mathrm{USD}$. Shaded areas indicate opportunity costs are higher than net income of afforestation.

It should be noted that crop production in China is often realized by small-scale farming. Large-scale farming requires bigger machines and investments. In addition, Chinese small-scale farmers can sell their harvest on the market at higher prices without using middlemen. Taking sugarcane as an example, the price when selling to individuals is three times higher than the selling price to a sugar company.

Table 6 shows the amount of tCERs generated by each alternative. The number of tCERs is determined by the specific tree species, regions and project durations. Eucalyptus produces the highest amount of tCERs during the whole study period with $1519.8 \mathrm{Mg}^{-1}$ ha $\mathrm{CO}_{2}$ sequestered (Table 6). This is because it is fast-growing and it is mostly planted in tropical areas, resulting in higher tree biomass. However, it should be noted that there are no tCERs generated, if the project duration is too short. This is because carbon credits could only be verified for at least five years and they will expire if the trees are harvested during the crediting period, in this case within the 10 years since the trees have been planted [38]. In other words, if farmers plant eucalyptus only for five years and then harvest it, no tCER will be issued. Therefore, the minimum project duration to get tCERs is 10 years. For Chinese fir, carbon accumulation is lower than that of eucalyptus due to its lower growth rate. Poplar produces significantly more tCERs in E, S, and SW regions compared with N, NE, and NW regions because of the favorable climatic conditions in eastern and southern regions (Table 6). For economic trees, carbon accumulation and consequently the number of tCERs is lower. The regional impact becomes obvious with fruit trees in the southern region producing more tCERs than in the northern parts. Nut trees 
generate more tCERs than fruit trees because of their higher tree biomass (Table 6). Bamboo produces the third highest number of tCERs, which indicates a high potential to sequester carbon.

The minimum present value of carbon revenues $\left(\mathrm{PV}_{\mathrm{CR}}\right)$ required to convince farmers to plant trees as calculated according to Equation 6 are given in Table 6 . The blank area indicates that no compensation is needed for forest alternatives because of their higher $\mathrm{NPV}_{\mathrm{A}}$ (Table 5). The total compensation to farmers strongly depends on the opportunity costs of cropland. For two-harvest corn and one-harvest sugarcane, the payments would be substantial because they are more profitable than forests (Table 5). However, for farmers cultivating other crop types such as one-harvest wheat, one-harvest corn or two-harvest rice, it could be more attractive to plant trees.

We also calculated the minimum price per tCER for different afforestation alternatives based on various crop types according to Equation 8 (Table 6). For ecological trees, the minimum price per tCER for converting crops with high NPVs is highest with $899 \mathrm{USD} \mathrm{Mg} \mathrm{CO}_{2}$, e.g., for converting sugarcane crops to forest with Chinese fir of 10-year rotation period. The minimum price per tCER is highly affected by the amount of tCER generated by forest alternatives. This price normally decreases with longer project duration because of the higher amount of tCERs generated per hectare. However, for afforestation with eucalyptus on land used for one-harvest wheat, one-harvest corn, and two-harvest rice cropland, the minimum price per tCER of projects with a longer duration (30 years) increases from 0 to 2.76, 1.04, and $2.28 \mathrm{USD} \mathrm{Mg}^{-1} \mathrm{CO}_{2}$ compared to projects with a duration of 10 years, respectively. This is due to the variation of discounted timber revenues, which are highest with 7365 USD ha $^{-1}$ for 10 years, and then decrease steeply to 2052 USD ha $^{-1}$ until year 30 (Table 5) based on decreasing growth rates and discounting effects. The highest minimum prices per tCER are reported for afforestation on cropland with two-harvest corn and one-harvest sugarcane (Table 6). This is a consequence of the high revenue loss when switching from highly profitable crops to forestry. However, since cash crops such as sugarcane are very labor intensive, households with little labor available may prefer to grow trees even if they earn less.

Note that the analysis is based on current timber prices and that we assume farmers can decide when and how much to harvest. However, in case harvesting is not permitted or severely curtailed due to strict cutting quota, farmers can hardly get revenues from selling timber after the end of national subsidies in the afforestation program. The results show the $\mathrm{NPV}_{\mathrm{A}}$ of eucalyptus in the first 10 to 20 years is sufficiently high (ranging from 4934 to $7365 \mathrm{USD} \mathrm{ha}^{-1}$ ) to cover the opportunity costs of crop types with a relatively low NPV (ranging from 1991 to 4367 USD ha $^{-1}$ ) (Table 5). For longer periods, especially after 20 years, the required compensation to keep the trees increases (Table 6). The minimum ptCER reaches $2.76 \mathrm{USD} \mathrm{Mg}^{-1} \mathrm{CO}_{2}$ to convince farmers not to harvest the trees until 30 years.

Generally, it is more profitable to plant economic trees, especially apple and nut trees, and there is no need for compensation for any of these forest alternatives (Table 6). Only farmers who plant orange trees on former sugarcane land need payments. To compensate the opportunity costs of changing the land use, for the first 10 years such farmers need about $767 \mathrm{USD} \mathrm{Mg}{ }^{-1} \mathrm{CO}_{2}$ because of (i) the low amount of tCERs generated; and (ii) the low yield and revenues of fruits trees in the initial years. The minimum price per tCER for afforestation with mango trees varies considerably, from 94 to $2680 \mathrm{USD} \mathrm{Mg}^{-1} \mathrm{CO}_{2}$, representing the significant effects of alternative crop types and the number of tCERs generated.

Similarly, the minimum price per tCER of bamboo varies from 0 to $927 \mathrm{USD} \mathrm{Mg}{ }^{-1} \mathrm{CO}_{2}$ depending on the project duration (Table 6), but there is an obvious trend that the compensation can be reduced with longer rotation periods. This is due to the rapid increase of tCERs based on the increasing growth rate of bamboo clumps during the overall study period (Figure S1).

The results reveal the significant impact of the project duration and tree species on the minimum price per tCER. In general, the minimum price decreases with the increase of the project duration because more tCERs are generated in later years, which is consistent with the findings of De Koning et al. (2005) [12]. However, the situation changes for fast-growing tree species like eucalyptus and poplar, with an minimum price per tCER even higher for older stands. This can be explained by the 
fast growth rate during the first 10 to 20 years. The present value of timber revenues per hectare for 10-year eucalyptus and 20-year poplar is significantly higher than that of shorter and longer periods.

The minimum price per tCER varies hugely from 0 to $2680 \mathrm{USD} \mathrm{Mg} \mathrm{Mg}_{2}$ depending on the afforestation alternatives (Table 6). Our results show a greater variation than that found by Phan et al. (2014) [19], most likely because of the different opportunity costs of cropland alternatives considered in our study. There are three kinds of costs of the afforestation projects, namely opportunity, implementation, and transaction costs. Opportunity costs are considered the most important factor, which on average can be up to three times higher than the transaction and implementation costs [43]. The average carbon price in China's national carbon market is expected to be $8 \mathrm{USD} \mathrm{Mg}{ }^{-1} \mathrm{CO}_{2}$ in 2020 and 15 USD $\mathrm{Mg}^{-1} \mathrm{CO}_{2}$ in 2025 [44], which can cover most of the costs per tCER for afforestation alternatives, except afforesting crop land that generates high grain revenues (two-harvest corn) or cash crops (one-harvest sugarcane).

This study determined the minimum price per tCER to make ecological and economic trees as well as bamboo forest economically attractive. Although economic trees are not officially included in the CDM afforestation framework, we assumed that afforestation with economic trees can also generate tCERs because (i) they indeed can contribute to carbon sequestration [30-33]; and (ii) afforestation projects in some countries like China include economic trees [21]. Therefore, our study followed the tCER rules to provide new insights and give policy recommendations under the condition that economic trees fulfil the respective requirements. We found fruit orchards to be a cost-efficient way to sequester carbon, especially nut trees since a considerable amount of carbon is stored, and there is no need for compensating the farmers. Bamboo also has a high potential to sequester carbon, even higher than many ecological tree species. However, the initial payments required for carbon sequestration can be high (varying from 2.31 to $13.62 \mathrm{USD} \mathrm{Mg}^{-1} \mathrm{CO}_{2}$ for replacing even economically less attractive crops) due to the low revenues from bamboo harvesting (Table 6). Switching to a longer rotation period of about 30 years reduced the compensation requirements to e.g., $0.54 \mathrm{USD} \mathrm{Mg}{ }^{-1} \mathrm{CO}_{2}$ for replacing two-harvest rice land use (Table 6). 
Table 6. Amount of temporary Certified Emission Reductions (tCER) ( $\mathrm{Mg} \mathrm{ha}^{-1}$ ) generated, present value of carbon revenues (PV $\left.\mathrm{CR}\right)\left(\mathrm{USD}^{-1}\right) \mathrm{required}^{-1}$ make afforestation economically attractive, and minimum price per tCER $\left(\mathrm{USD} \mathrm{Mg} \mathrm{Mg}_{2}\right)$ for different afforestation alternatives.

\begin{tabular}{|c|c|c|c|c|c|c|c|c|c|c|c|c|c|}
\hline \multirow[b]{2}{*}{$\begin{array}{l}\text { Afforestation } \\
\text { Alternatives }\end{array}$} & \multirow[b]{2}{*}{ Region(s) } & \multirow[b]{2}{*}{$\begin{array}{l}\text { Project } \\
\text { Duration } \\
\text { (year) }\end{array}$} & \multirow[b]{2}{*}{$\begin{array}{c}\text { tCER } \\
\text { Generated } \\
\left(\mathrm{Mg} \mathrm{ha}^{-1}\right)\end{array}$} & \multicolumn{5}{|c|}{$\mathrm{PV}_{\mathrm{CR}}\left(\mathrm{USD} \mathrm{ha}^{-1}\right)$} & \multicolumn{5}{|c|}{ Costs Per tCER (USD $\mathrm{Mg}^{-1} \mathrm{CO}_{2}$ ) } \\
\hline & & & & $\begin{array}{l}\text { One-Harvest } \\
\text { Wheat }\end{array}$ & $\begin{array}{l}\text { One-Harvest } \\
\text { Corn }\end{array}$ & $\begin{array}{l}\text { Two-Harvest } \\
\text { Corn }\end{array}$ & $\begin{array}{l}\text { Two-Harvest } \\
\text { Rice }\end{array}$ & $\begin{array}{l}\text { One-Harvest } \\
\text { Sugarcane }\end{array}$ & $\begin{array}{l}\text { One-Harvest } \\
\text { Wheat }\end{array}$ & $\begin{array}{l}\text { One-Harvest } \\
\text { Corn }\end{array}$ & $\begin{array}{l}\text { Two-Harvest } \\
\text { Corn }\end{array}$ & $\begin{array}{l}\text { Two-Harvest } \\
\text { Rice }\end{array}$ & $\begin{array}{l}\text { One-Harvest } \\
\text { Sugarcane }\end{array}$ \\
\hline \multirow[t]{4}{*}{ Eucalyptus } & C & $\begin{array}{c}5 \\
\text { (normal) }\end{array}$ & 0.00 & & & 3269.39 & & $40,901.76$ & & & & & \\
\hline & & 10 & 147.85 & & & 4898.53 & & $73,461.96$ & & & 33.13 & & 496.86 \\
\hline & & 20 & 743.86 & 19.96 & & $15,614.86$ & & $130,497.28$ & 0.03 & & 20.99 & & 175.43 \\
\hline & & 30 & 1539.80 & 4250.52 & 1608.12 & $24,093.13$ & 3503.51 & $170,267.01$ & 2.76 & 1.04 & 15.65 & 2.28 & 110.58 \\
\hline \multirow[t]{6}{*}{ Chinese fir } & E, N, NE & $\begin{array}{c}10 \\
\text { (normal) }\end{array}$ & 80.88 & & & 4143.18 & & $72,706.61$ & & & 51.23 & & 898.92 \\
\hline & & 20 & 367.13 & & & 8775.29 & & $123,657.72$ & & & 23.90 & & 336.82 \\
\hline & & 30 & 827.42 & & & $15,954.20$ & & $162,128.08$ & & & 19.28 & & 195.94 \\
\hline & $\begin{array}{c}\text { NW, S, } \\
\text { SW }\end{array}$ & $\begin{array}{c}10 \\
\text { (normal) }\end{array}$ & 85.96 & & & 4143.18 & & $72,706.61$ & & & 48.20 & & 845.86 \\
\hline & & 20 & 398.53 & & & 8775.29 & & $123,657.72$ & & & 22.02 & & 310.28 \\
\hline & & 30 & 799.40 & & & $15,954.20$ & & $162,128.08$ & & & 19.96 & & 202.81 \\
\hline \multirow[t]{6}{*}{ Poplar } & E, S, SW & $\begin{array}{c}10 \\
\text { (normal) }\end{array}$ & 153.93 & 1878.11 & 913.08 & $11,185.36$ & 1527.72 & $79,748.79$ & 12.20 & 5.93 & 72.66 & 9.92 & 518.07 \\
\hline & & 20 & 683.90 & & & 9324.46 & & $124,206.89$ & & & 13.63 & & 181.61 \\
\hline & & 30 & 1142.86 & 187.67 & & $20,030.28$ & & $166,204.16$ & 0.16 & & 17.53 & & 145.43 \\
\hline & $\begin{array}{l}\text { N, NE, } \\
\text { NW }\end{array}$ & $\begin{array}{c}10 \\
\text { (normal) }\end{array}$ & 21.95 & 1878.11 & 913.08 & NA & NA & NA & 85.57 & 41.60 & NA & NA & NA \\
\hline & & 20 & 193.73 & & & NA & NA & NA & & & NA & NA & NA \\
\hline & & 30 & 458.93 & 187.67 & & NA & NA & NA & 0.41 & & NA & NA & NA \\
\hline \multirow[t]{3}{*}{ Apple tree } & $\begin{array}{l}\text { N, NE, } \\
\text { NW }\end{array}$ & 10 & -21.10 & & & NA & NA & NA & & & NA & NA & NA \\
\hline & & 20 & 36.33 & & & NA & NA & NA & & & NA & NA & NA \\
\hline & & 30 & 84.45 & & & NA & NA & NA & & & NA & NA & NA \\
\hline \multirow[t]{3}{*}{ Orange tree } & $\mathrm{s}$ & 10 & 26.52 & NA & NA & & & $20,341.76$ & NA & NA & & & 767.17 \\
\hline & & 20 & 146.10 & NA & NA & & & & NA & NA & & & \\
\hline & & 30 & 295.64 & NA & NA & & & & NA & NA & & & \\
\hline \multirow[t]{3}{*}{ Mango tree } & S & 10 & 26.52 & NA & NA & 2490.47 & & $71,053.90$ & NA & NA & 93.93 & & 2679.74 \\
\hline & & 20 & 146.10 & NA & NA & & & $90,644.23$ & NA & NA & & & 620.42 \\
\hline & & 30 & 295.64 & NA & NA & & & $103,878.76$ & NA & NA & & & 351.37 \\
\hline \multirow[t]{3}{*}{ Chestnut } & E & 10 & 56.85 & & & & & & & & & & \\
\hline & & 20 & 199.65 & & & & & & & & & & \\
\hline & & 30 & 320.16 & & & & & & & & & & \\
\hline \multirow[t]{3}{*}{ Walnut } & $\mathrm{N}$ & 10 & 17.85 & & & NA & NA & NA & & & NA & NA & NA \\
\hline & & 20 & 105.63 & & & NA & NA & NA & & & NA & NA & NA \\
\hline & & 30 & 216.14 & & & NA & NA & NA & & & NA & NA & NA \\
\hline
\end{tabular}


Table 6. Cont

\begin{tabular}{|c|c|c|c|c|c|c|c|c|c|c|c|c|c|}
\hline \multirow[b]{2}{*}{$\begin{array}{l}\text { Afforestation } \\
\text { Alternatives }\end{array}$} & \multirow[b]{2}{*}{ Region(s) } & \multirow[b]{2}{*}{$\begin{array}{c}\text { Project } \\
\text { Duration } \\
\text { (year) }\end{array}$} & \multirow[b]{2}{*}{$\begin{array}{c}\text { tCER } \\
\text { Generated } \\
\left(\mathrm{Mg} \mathrm{ha}^{-1}\right)\end{array}$} & \multicolumn{5}{|c|}{$\mathrm{PV}_{\mathrm{CR}}\left(\mathrm{USD} \mathrm{ha}^{-1}\right)$} & \multicolumn{5}{|c|}{ Costs Per tCER (USD $\mathrm{Mg}^{-1} \mathrm{CO}_{2}$ ) } \\
\hline & & & & $\begin{array}{l}\text { One-Harvest } \\
\text { Wheat }\end{array}$ & $\begin{array}{l}\text { One-Harvest } \\
\text { Corn }\end{array}$ & $\begin{array}{l}\text { Two-Harvest } \\
\text { Corn }\end{array}$ & $\begin{array}{l}\text { Two-Harvest } \\
\text { Rice }\end{array}$ & $\begin{array}{l}\text { One-Harvest } \\
\text { Sugarcane }\end{array}$ & $\begin{array}{l}\text { One-Harvest } \\
\text { Wheat }\end{array}$ & $\begin{array}{l}\text { One-Harvest } \\
\text { Corn }\end{array}$ & $\begin{array}{l}\text { Two-Harvest } \\
\text { Corn }\end{array}$ & $\begin{array}{l}\text { Two-Harvest } \\
\text { Rice }\end{array}$ & $\begin{array}{l}\text { One-Harvest } \\
\text { Sugarcane }\end{array}$ \\
\hline \multirow[t]{3}{*}{ Bamboo* $^{*}$} & $\mathrm{E}, \mathrm{S}, \mathrm{SW}$ & 10 & 85.30 & 1161.91 & 196.87 & $10,469.16$ & 811.52 & $79,032.59$ & 13.62 & 2.31 & 122.74 & 9.51 & 926.57 \\
\hline & & 20 & 440.65 & 1240.81 & & $16,835.71$ & 653.71 & $131,718.14$ & 2.82 & & 38.21 & 1.48 & 298.91 \\
\hline & & 30 & 1010.67 & 1294.12 & & $21,136.73$ & 547.10 & $167,310.61$ & 1.28 & & 20.91 & 0.54 & 165.54 \\
\hline
\end{tabular}




\subsection{Sensitivity Analysis}

Because of uncertainties concerning future economic conditions and developments, we conducted a sensitivity analysis to assess the changes of minimum prices per tCER using different timber, fruit and grain prices, interest rates, and certification costs (Table 7). Further, we compared the minimum prices per tCER with and without considering soil organic carbon in tCER generation, given that SOC is often not properly included in CDM afforestation projects [9]. We selected one tree species from each tree group to represent the respective changes. We chose poplar (ecological tree), chestnut trees (economic tree), and bamboo since the minimum prices per tCER of these tree species reflect different aspects of relevant changes. For comparison, we selected one-harvest wheat and two-harvest corn as crop alternatives because (i) their revenues differ significantly, and (ii) they grow in different regions.

The minimum compensation required to make tree planting profitable declines with rising timber prices. With timber prices increasing by $25 \%$, poplar afforestation becomes economically attractive in the northern regions even without compensation (Table 7). In contrast, the required compensation rises with increasing prices of crop grains. Note that huge afforestation activities in a region might lead to (i) reduced timber prices in the longer run due to an excess of timber supply, and (ii) increased crop prices due to reduced grain production. Both effects would reinforce each other and lead to higher minimum prices per tCER.

The interest rate level also has a significant impact on the minimum tCER prices (Table 7). In general, higher interest rates lead to lower NPV from timber, mainly because revenues occur only at the end of the project duration, and are therefore strongly affected by discounting. However, the situation for bamboo is different because we assume bamboo to be harvested by selective cutting after year 3 (1/6 annually) and clear cut at the end of the project. This means, revenues are generated continuously and relatively early and, are thus, less affected by discounting.

The afforestation alternatives with a minimum ptCER higher than 10 USD $\mathrm{Mg}^{-1} \mathrm{CO}_{2}$ are less affected by the change of certification costs, because these costs are relatively low compared with

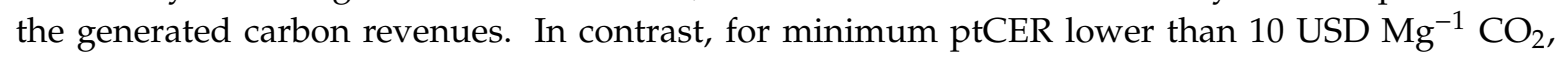
the certification costs can sum up to about $85 \%$ of the carbon price. Concerning the influence of SOC sequestration, our results show that the minimum ptCER increases up to three times without considering tCERs generated in soils. 
Table 7. Sensitivity analysis for the minimum price per tCER for different afforestation alternatives (USD $\left.\mathrm{Mg}^{-1} \mathrm{CO}_{2}\right)$.

\begin{tabular}{|c|c|c|c|c|c|c|c|c|c|c|c|c|c|c|c|c|c|c|}
\hline & \multicolumn{3}{|c|}{$\begin{array}{l}\text { Poplar (N, NE, NW), } \\
\text { Converted from } \\
\text { One-Harvest Wheat }\end{array}$} & \multicolumn{3}{|c|}{$\begin{array}{l}\text { Poplar (E, S, SW), Converted } \\
\text { from Two-Harvest Corn }\end{array}$} & \multicolumn{3}{|c|}{$\begin{array}{l}\text { Chestnut, Converted from } \\
\text { One-Harvest Wheat }\end{array}$} & \multicolumn{3}{|c|}{$\begin{array}{l}\text { Chestnut, Converted from } \\
\text { Two-Harvest Corn }\end{array}$} & \multicolumn{3}{|c|}{$\begin{array}{l}\text { Bamboo, Converted from } \\
\text { One-Harvest Wheat }\end{array}$} & \multicolumn{3}{|c|}{$\begin{array}{l}\text { Bamboo, Converted } \\
\text { from Two-Harvest Corn }\end{array}$} \\
\hline & $\begin{array}{c}10 \\
\text { Years }\end{array}$ & $\begin{array}{c}20 \\
\text { Years }\end{array}$ & $\begin{array}{c}30 \\
\text { Years }\end{array}$ & $\begin{array}{c}10 \\
\text { Years }\end{array}$ & $\begin{array}{c}20 \\
\text { Years }\end{array}$ & $\begin{array}{c}30 \\
\text { Years }\end{array}$ & 10 Years & 20 Years & 30 Years & 10 Years & 20 Years & 30 Years & $\begin{array}{c}10 \\
\text { Years }\end{array}$ & $\begin{array}{c}20 \\
\text { Years }\end{array}$ & $\begin{array}{c}30 \\
\text { Years }\end{array}$ & $\begin{array}{c}10 \\
\text { Years }\end{array}$ & $\begin{array}{c}20 \\
\text { Years }\end{array}$ & $\begin{array}{c}30 \\
\text { Years }\end{array}$ \\
\hline \multicolumn{19}{|c|}{ Timber/fruit price } \\
\hline $75 \%$ & 215.43 & (3.13) & 9.48 & 91.18 & 21.92 & 21.17 & (940.24) & (705.44) & $(624.30)$ & $(776.54)$ & $(627.33)$ & (562.33) & 29.91 & 7.48 & 3.76 & 139.03 & 42.87 & 23.39 \\
\hline $100 \%$ & 85.57 & (32.37) & 0.41 & 72.66 & 13.63 & 17.5 & (1426.48) & (1049.23) & (925.18) & (1262.78) & (971.12) & (863.21) & 13.62 & 2.82 & 1.28 & 122.74 & 38.21 & 20.91 \\
\hline $125 \%$ & $(44.28)$ & $(61.61)$ & $(8.66)$ & 54.15 & 5.35 & 13.88 & (1912.72) & (1393.02) & (1226.07) & (1749.02) & (1314.91) & (1164.09) & $(2.67)$ & $(1.85)$ & $(1.20)$ & 106.45 & 33.54 & 18.44 \\
\hline \multicolumn{19}{|l|}{ Grain price } \\
\hline $75 \%$ & $(130.62)$ & (73.40) & (21.63) & (31.07) & (25.49) & (12.26) & (1509.94) & (1089.05) & (956.78) & (1543.64) & (1105.13) & (969.54) & $(42.01)$ & (15.23) & (8.73) & (64.47) & $(22.51)$ & (12.77) \\
\hline $100 \%$ & 85.57 & (32.37) & 0.41 & 72.66 & 13.63 & 17.53 & (1426.48) & (1049.23) & (925.18) & (1262.78) & (971.12) & (863.21) & 13.62 & 2.82 & 1.28 & 122.74 & 38.21 & 20.91 \\
\hline $125 \%$ & 301.76 & 8.67 & 22.45 & 176.40 & 52.76 & 47.31 & (1343.02) & (1009.41) & (893.59) & $(981.92)$ & (837.11) & (756.87) & 69.25 & 20.86 & 11.29 & 309.95 & 98.92 & 54.60 \\
\hline \multicolumn{19}{|l|}{ Interest rate } \\
\hline $2 \%$ & 20.01 & (57.95) & (13.60) & 64.81 & 5.75 & 11.10 & (1511.81) & (1091.39) & (948.73) & (1344.07) & (1013.28) & (887.92) & $(9.33)$ & $(4.01)$ & $(2.30)$ & 102.48 & 30.68 & 15.92 \\
\hline $4 \%$ & 85.57 & (32.37) & 0.41 & 72.66 & 13.63 & 17.53 & (1426.48) & (1049.23) & (925.18) & (1262.78) & (971.12) & (863.21) & 13.62 & 2.82 & 1.28 & 122.74 & 38.21 & 20.91 \\
\hline $6 \%$ & 148.7 & $(6.79)$ & 15.11 & 80.37 & 21.28 & 23.80 & (1348.08) & (1010.12) & (903.67) & (1187.89) & (931.60) & (840.00) & 3.80 & 0.45 & 0.12 & 110.57 & 36.75 & 21.45 \\
\hline \multicolumn{19}{|c|}{$\begin{array}{l}\text { Certification costs (USD } \\
\text { ha }^{-1} \text { every } 5 \text { years) }\end{array}$} \\
\hline 0 & 85.57 & (32.37) & 0.41 & 72.66 & 13.63 & 17.53 & (1426.48) & (1049.23) & (925.18) & (1262.78) & (971.12) & (863.21) & 13.62 & 2.82 & 1.28 & 122.74 & 38.21 & 20.91 \\
\hline 50 & 88.98 & (31.72) & 0.76 & 73.15 & 13.82 & 17.67 & (1425.16) & (1048.60) & (924.69) & (1261.46) & (970.49) & (862.71) & 14.50 & 3.10 & 1.44 & 123.62 & 38.49 & 21.07 \\
\hline 100 & 92.40 & (31.07) & 1.10 & 73.64 & 14.00 & 17.81 & (1423.85) & (1047.97) & (924.19) & (1260.14) & (969.86) & (862.21) & 15.38 & 3.39 & 1.60 & 124.49 & 38.78 & 21.23 \\
\hline \multicolumn{19}{|c|}{ SOC sequestration } \\
\hline Included & 85.57 & (32.37) & 0.41 & 72.66 & 13.63 & 17.53 & (1426.48) & (1049.23) & (925.18) & (1262.78) & (971.12) & $(863.21)$ & 13.62 & 2.82 & 1.28 & 122.74 & 38.21 & 20.91 \\
\hline Not included & 334.11 & $(153.24)$ & 1.89 & 358.51 & 54.62 & 71.59 & (5445.54) & (4865.47) & (4771.45) & $(4820.61)$ & (4503.25) & (4451.82) & 41.95 & 9.59 & 5.09 & 377.96 & 130.14 & 83.18 \\
\hline
\end{tabular}

Note: C, E, N, NE, NW, S, and SW are abbreviations for China, and the eastern, northern, northeastern, northwestern, southern, and southwestern region. One- or two-harvest means the crops are harvested once or twice annually, respectively. Numbers in bracket indicate negative value, which means no compensation is needed for forest alternatives. Bold figures indicate the results of Table 6. $1 \mathrm{RMB}=0.15 \mathrm{USD}$. 


\subsection{Uncertainty Analysis}

This study comprehensively determined the extent of carbon sequestration by afforestation with different tree species and assessed the costs and benefits of afforestation projects from the farmers' perspective in China. Several uncertainties and bias could have affected the estimation of the carbon sequestration potential and the collection of economic data from the farmers. We controlled uncertainties in two ways. First, we applied the models and results of previously published studies to determine the carbon sequestration potential after afforestation. These findings are based on large sample sizes and therefore the sampling error is minimized in the estimation of tCERs. Second, for the economic data collection, we carried out at least five interviews for each species: if the values given by the interviewees varied by more than $10 \%$ we interviewed more people until we obtained a variation lower than $10 \%$. Then we calculated the average of these answers. Most farmers gave very similar answers, so we are confident that our results provide well-founded and realistic average data. However, given the relatively small sample size, the representativity of our results for the diverse overall area might be limited. Further, it should be noted that we estimated the carbon sequestration potential based on average regional site qualities. In consequence, the timber revenues and tCER generated can be higher at sites with better soil quality and overestimated for poorer soil quality.

Besides the analyzed economic variables, some additional factors might play a role in the decision-making of farmers. Possible reasons why landowners do not switch to more profitable land uses are (i) lacking planting skills for trees or the most profitable crops; (ii) limited market access for particular crops or tree products (e.g., transportation network for timber); (iii) insufficient household labor to grow more labor intensive and profitable crops (e.g. sugarcane); (iv) maintaining the tradition of growing certain crops (e.g., for self-consumption).

\section{Conclusions}

Afforestation programs have a great potential to sequester carbon. The revenues of selling carbon credits can in turn contribute to finance the afforestation costs. Our study determined the carbon sequestration potential of afforestation programs considering both tree biomass and soils and compared the costs and benefits of carbon sequestration by different tree species.

Economic trees sequester less carbon than ecological trees and bamboo. Among economic trees, nut trees sequester more carbon than fruit trees. The regional context significantly influences the carbon sequestration potential with more carbon sequestered in southern and eastern regions than in northern parts. Bamboo also shows a remarkable carbon sequestration potential, which is even higher than Chinese fir and poplar in northern regions. Older bamboo stands ( $>30$ years) could even be stronger carbon accumulators than eucalyptus, although the latter shows the greatest average carbon sequestration capacity during the study period.

Generally, it is less attractive to afforest highly productive cropland because of the high opportunity costs. The minimum price per tCER decreases with increasing project duration, except for some alternatives with fast-growing trees like eucalyptus and poplar, for which the minimum price per tCER is higher with a 30-year duration compared to a 20-year duration.

Tree product revenues differ depending on the tree species, which results in a significant variation of economic net benefits. However, our results also show that for most afforestation alternatives no compensation is needed to convert cropland with relatively low revenues such as one-harvest wheat, one-harvest corn, and two-harvest rice. For ecological trees, afforestation is profitable if farmers harvest the timber after the normal rotation period of each tree species. Furthermore, with the recent increase of timber demand in China, the timber price has increased substantially, which makes afforestation projects even more attractive. For economic trees, the amount of carbon sequestered is low, but selling fruits and nuts is quite profitable. Therefore, in most cases, there is no compensation needed for afforestation efforts. Further, our study suggests that bamboo afforestation can become economically more attractive, when carbon revenues are included. The same holds for other afforestation alternatives which require compensations. If the carbon credits generated would be traded, e.g., in a Chinese 
carbon market, the opportunity costs of alternative land uses could be fully compensated, except for afforestation on highly attractive cropland. However, considering the uncertain development of future China's carbon credit demand and supply [45], it could be advantageous to trade CER generated by China's afforestation projects in an international emission trading system.

Our study provides a comprehensive economic valuation of carbon sequestration by afforestation projects in China considering ecological trees, economic trees and bamboo. It demonstrates that the attractiveness of different afforestation alternatives is strongly context dependent and varies substantially across regions. The comparison of costs and benefits can help to determine efficient ways to sequester carbon by afforestation projects. The findings can contribute to the design of carbon sequestration projects in China [45]. The methodology and results can be adapted and transferred to other regions in the developing world.

Supplementary Materials: The following are available online at http://www.mdpi.com/1999-4907/10/9/754/s1. Figure S1. Temporal patterns of the amount of carbon sequestration (including biomass and soil carbon) after afforestation with various tree types on cropland.

Author Contributions: All authors contributed to the design and development of this manuscript. G.H., X.L. and C.O.D. carried out the fieldwork, G.H. analyzed the data and prepared the first draft of the manuscript with R.O. and C.O.D. and R.O. revised and edited the manuscript.

Funding: This research was funded by the Research Grants Council of the Hong Kong Special Administrative Region, China (project No. 12305116).

Acknowledgments: The work described in this paper has been supported by grants from the Research Grants Council of the Hong Kong Special Administrative Region, China (project No. 12305116) and Kwok Yat Wai and Madam Kwok Chung Bo Fun Graduate School Development Fund.

Conflicts of Interest: The authors declare no conflict of interest. The sponsors had no role in the design, execution, interpretation, or writing of the study.

\section{References}

1. IPCC. IPCC Special Report on Land Use, Land-Use Change and Forestry; Cambridge University Press: Cambridge, $\mathrm{UK}, 2007$.

2. Pan, Y.; Birdsey, R.A.; Fang, J.; Houghton, R.; Kauppi, P.E.; Kurz, W.A.; Phillips, O.L.; Shvidenko, A.; Lewis, S.L.; Canadell, J.G.; et al. A large and persistent carbon sink in the world's forests. Science 2011, 333, 988-993. [CrossRef] [PubMed]

3. Le Quéré, C.; Andrew, R.M.; Friedlingstein, P.; Sitch, S.; Hauck, J.; Pongratz, J.; Pickers, P.A.; Korsbakken, J.I.; Peters, G.P.; Canadell, J.G.; et al. Global Carbon Budget 2018. Earth Syst. Sci. Data 2018, 10, 2141-2194. [CrossRef]

4. Bastin, J.F.; Finegold, Y.; Garcia, C.; Mollicone, D.; Rezende, M.; Routh, D.; Zohner, C.M.; Crowther, T.W. The global tree restoration potential. Science 2019, 365, 76-79. [CrossRef]

5. Le, H.D.; Smith, C.; Herbohn, J. What drives the success of reforestation projects in tropical developing countries? The case of the Philippines. Glob. Environ. Chang. 2014, 24, 334-348. [CrossRef]

6. Komba, C.; Muchapondwa, E. An analysis of factors affecting household willingness to participate in the REDD+ programme in Tanzania. Clim. Dev. 2014, 9, 244-257. [CrossRef]

7. Chenost, C.; Gardette, Y.M.; Demenois, J.; Grondard, N.; Perrier, M.; Wemaere, M. Bringing Forest Carbon Projects to the Market; UNEP: Paris, France, 2010; pp. 67-103.

8. NDRC. Report on the Implementation of the 2007 Plan for National Economic and Social Development and on the 2008 Draft Plan for National Economic and Social Development; National Development and Reform Commission: Beijing, China, 2008.

9. Van der Gaast, W.; Sikkema, R.; Vohrer, M. The contribution of forest carbon credit projects to addressing the climate change challenge. Clim. Policy 2018, 18, 42-48. [CrossRef]

10. Hanley, N.; Barbier, E.B.; Barbier, E. Pricing Nature: Cost-Benefit Analysis and Environmental Policy; Edward Elgar Publishing: Cheltenham, UK, 2009.

11. Yemshanov, D.; McKenney, D.W.; Hatton, T.; Fox, G. Investment attractiveness of afforestation in Canada inclusive of carbon sequestration benefits. Can. J. Agric. Econ./Rev. Can. D'agroeconomie 2005, 53, 307-323. [CrossRef] 
12. De Koning, F.; Olschewski, R.; Veldkamp, E.; Benítez, P.; Lopez-Ulloa, M.; Schlichter, T.; de Urquiza, M. The ecological and economic potential of carbon sequestration in forests: Examples from South America. AMBIO J. Hum. Environ. 2005, 34, 224-230. [CrossRef]

13. Rooney, M.; Paul, K.I. Assessing policy and carbon price settings for incentivising reforestation activities in a carbon market: An Australian perspective. Land Use Policy 2017, 67, 725-732. [CrossRef]

14. $\mathrm{Xu}, \mathrm{D}$. The potential for reducing atmospheric carbon by large-scale afforestation in China and related cost/benefit analysis. Biomass Bioenergy 1995, 8, 337-344. [CrossRef]

15. Caldwell, I.M.; Maclaren, V.W.; Chen, J.M.; Ju, W.M.; Zhou, S.; Yin, Y.; Boland, A. An integrated assessment model of carbon sequestration benefits: A case study of Liping county, China. J. Environ. Manag. 2007, 85, 757-773. [CrossRef]

16. Wang, C.; Ouyang, H.; Maclaren, V.; Yin, Y.; Shao, B.; Boland, A.; Tian, Y. Evaluation of the economic and environmental impact of converting cropland to forest: A case study in Dunhua county, China. J. Environ. Manag. 2007, 85, 746-756. [CrossRef]

17. Shi, W.; Wang, K. Assessment of ecological, economic and social impacts of grain for green on the counties of north Shaanxi in the Loess Plateau, China: A case study of Mizhi County. Afr. J. Biotechnol. 2011, 10, 15763-15769. [CrossRef]

18. Yang, H.; Li, X. Potential variation in opportunity cost estimates for REDD+ and its causes. For. Policy Econ. 2018, 95, 138-146. [CrossRef]

19. Phan, T.H.D.; Brouwer, R.; Davidson, M. The economic costs of avoided deforestation in the developing world: A meta-analysis. J. For. Econ. 2014, 20,1-16.

20. Ickowitz, A.; Sills, E.; de Sassi, C. Estimating smallholder opportunity costs of REDD+: A pantropical analysis from households to carbon and back. World Dev. 2017, 95, 15-26. [CrossRef]

21. Delang, C.O.; Yuan, Z. China's Grain for Green Program: A Review of the Largest Ecological Restoration and Rural Development Program in the World; Springer: Cham, Switzerland, 2016; pp. 37-97.

22. Zhang, C.; Ju, W.; Chen, J.; Fang, M.; Wu, M.; Chang, X.; Wang, T.; Wang, X. Sustained Biomass Carbon Sequestration by China's Forests from 2010 to 2050. Forests 2018, 9, 689. [CrossRef]

23. Fang, J.; Chen, A.; Peng, C.; Zhao, S.; Ci, L. Changes in forest biomass carbon storage in China between 1949 and 1998. Science 2001, 292, 2320-2322. [CrossRef]

24. Wang, K.; Hu, D.; Deng, J.; Shangguan, Z.; Deng, L. Biomass carbon storages and carbon sequestration potentials of the Grain for Green Program-Covered Forests in China. Ecol. Evol. 2018, 8, 7451-7461. [CrossRef]

25. Jacobs, D.F.; Selig, M.F.; Severeid, L.R. Aboveground carbon biomass of plantation-grown American chestnut (Castanea dentata) in absence of blight. For. Ecol. Manag. 2009, 258, 288-294. [CrossRef]

26. Kukal, S.S.; Bawa, S.S. Soil organic carbon stock and fractions in relation to land use and soil depth in the degraded Shiwaliks hills of lower Himalayas. Land Degrad. Dev. 2014, 25, 407-416. [CrossRef]

27. Deng, L.; Shangguan, Z.P. Afforestation drives soil carbon and nitrogen changes in China. Land Degrad. Dev. 2017, 28, 151-165. [CrossRef]

28. Li, D.; Niu, S.; Luo, Y. Global patterns of the dynamics of soil carbon and nitrogen stocks following afforestation: A meta-analysis. New Phytol. 2012, 195, 172-181. [CrossRef] [PubMed]

29. Hou, G.; Delang, C.O.; Lu, X.; Gao, L. Soil organic carbon storage varies with stand ages and soil depths following afforestation. Ann. For. Res. 2019. accepted. [CrossRef]

30. Wu, T.; Wang, Y.; Yu, C.; Chiarawipa, R.; Zhang, X.; Han, Z.; Wu, L. Carbon sequestration by fruit trees-Chinese apple orchards as an example. PLoS ONE 2012, 7, e38883. [CrossRef] [PubMed]

31. Ren, H.; Li, L.; Liu, Q.; Wang, X.; Li, Y.; Hui, D.; Jian, S.; Wang, J.; Yang, H.; Lu, H.; et al. Spatial and temporal patterns of carbon storage in forest ecosystems on Hainan island, southern China. PLoS ONE 2014, 9, e108163. [CrossRef] [PubMed]

32. Shen, H.T.; Wang, X.X.; Zhao, Y.X.; Liu, X. Carbon and nitrogen reserves of 10a walnut forest ecosystem in Taihang Mountain, Hebei province. J. Sichuan Agric. Univ. 2017, 35, 208-212. (In Chinese)

33. Peng, F.R.; Wang, L.G. Growth and biological productivity of chestnut stands with different densities (Doctoral dissertation). Econ. For. Res. 1998, 16, 12-15. (In Chinese)

34. Zhang, H.; Zhuang, S.; Sun, B.; Ji, H.; Li, C.; Zhou, S. Estimation of biomass and carbon storage of moso bamboo (Phyllostachys pubescens Mazel ex Houz.) in southern China using a diameter-age bivariate distribution model. For. Int. J. For. Res. 2014, 87, 674-682. [CrossRef] 
35. NFGA. The 8th National Forest Inventory. 2018. Available online: http://english.forestry.gov.cn/index.php? option=com_content\&view=article\&id=2:forest-resources-in-china\&catid=10\&Itemid=134 (accessed on 6 June 2019).

36. Yen, T.M.; Lee, J.S. Comparing aboveground carbon sequestration between moso bamboo (Phyllostachys heterocycla) and China fir (Cunninghamia lanceolata) forests based on the allometric model. For. Ecol. Manag. 2011, 261, 995-1002. [CrossRef]

37. Olschewski, R.; Benítez, P.; de Koning, G.H.J.; Schlichter, T. How attractive are forest carbon sinks? Economic insights into supply and demand of certified emission reductions. J. For. Econ. 2005, 11, 77-94. [CrossRef]

38. UNFCCC. Afforestation and Reforestation Projects under the Clean Development Mechanism: A Reference Manual; UNFCCC: Bonn, Germany, 2013.

39. Olschewski, R.; Benítez, P. Secondary forests as temporary carbon sinks? The economic impact of accounting methods on reforestation projects in the tropics. Ecol. Econ. 2005, 55, 380-394. [CrossRef]

40. Zhou, S.; Yin, Y.; Xu, W.; Ji, Z.; Caldwell, I.; Ren, J. The costs and benefits of reforestation in Liping County, Guizhou Province, China. J. Environ. Manag. 2007, 85, 722-735. [CrossRef]

41. Zang, Y.Q. Development of experience receipt table for Chinese fir plantation in Weimin forest farm. Fujian For. Technol. 2006, 33, 42-51. (In Chinese)

42. Zhao, B.B.; Zai, W.Y.; Hao, K.J.; Tao, G.L.; Lu, F.D. The application of richards growth function on growth prediction of fast-growing and high-yield 107-poplar plantations. J. Shandong Agric. Univ. (Nat. Sci. Ed.) 2010, 41, 23-26. (In Chinese)

43. Rakatama, A.; Pandit, R.; Ma, C.; Iftekhar, S. The costs and benefits of REDD+: A review of the literature. For. Policy Econ. 2017, 75, 103-111. [CrossRef]

44. Slater, H.; De Boer, D.; Wang, S.; Qian, G.Q. Carbon Price in China. Available online: www.efchina.org/Attachments/Report/report-lceg.../2018年中国碳价调查-v4.pdf (accessed on 6 June 2019).

45. Zhou, W.; Gong, P.; Gao, L. A review of carbon forest development in China. Forests 2017, 8, 295. [CrossRef]

(C) 2019 by the authors. Licensee MDPI, Basel, Switzerland. This article is an open access article distributed under the terms and conditions of the Creative Commons Attribution (CC BY) license (http://creativecommons.org/licenses/by/4.0/). 